\title{
Postupy používané učiteli ve vztahu k žákovské chybě při interakci s celou trrídou
}

\author{
Martin Majcík \\ Ústav pedagogických věd, Filozofická fakulta, Masarykova univerzita \\ Redakci zasláno 15. 6. 2018 / upravená verze obdržena 16. 9. 2018 / \\ / k uveřejnění přijato 17. 9. 2018
}

\begin{abstract}
Abstrakt: Cílem výzkumné studie je identifikovat postupy, které učitelé volí ve spojitosti s žákovskou chybou. Pozornost je věnována výhradně těm situacím, jež se pojí $\mathrm{s}$ chybami, ke kterým dochází při interakci učitele $\mathrm{s}$ celou tř́́dou. $\mathrm{V}$ teorii je představena definice chyby a vývoj jejího pojetí v kontextu výuky. Dále jsou představeny jednotlivé oblasti učitelské práce s chybným žákovským výkonem. Výzkumné šetření má kvalitativní charakter a použity byly metody pozorování a rozhovoru. Sběr dat byl realizován ve výuce českého jazyka v devátém ročníku základní školy. Výsledkem šetření je vymezení čtyř postupů, které učitelé v rámci práce s chybou realizují. Dva postupy představují způsob reakce na chybný výsledek v odlišných výukových situacích a definovány jsou jako adaptivní reakce na chybu a relativizace chybné odpovědi. Zbylé dva postupy chybě předcházejí a jejich prostřednictvím učitel ovlivňuje význam chyby v sociálním prostředí dané školní třídy. Jedná se o ochranu před chybnou odpovědí u vybraných žáků a minimalizaci negativního pojetí chyby.
\end{abstract}

Klíčová slova: chyba, chybný výkon, učitelské postupy, učitelská práce s chybou, výuková komunikace, interakce s žáky

Žákovská chyba je fenoménem, kterému je pozornost věnována v rámci celé řady oblastí českého pedagogického výzkumu, ze kterých můžeme jmenovat například téma hodnocení (Slavík, 2003), zpětnou vazbu (Šed'ová \& Švaříček, 2012) či výuku cizích jazyků (Ondráková, 2014). Chyba je dle Borasiho (1994, s. 170) nedílnou a důležitou součástí výuky, která pro učitele může představovat vhodný nástroj na podporu žákovského učení. Zejména v posledních dekádách je v odborném diskurzu patrný zájem o porozumění způsobu, jak učitel na chybu reaguje a jak s ní ve výuce dále pracuje (Bray, 2011; Kalová, 2018; Schleppenbach et al., 2007; Steuer, Rosentritt-Brunn, \& Dresel, 2013). Předložená studie si klade za cíl identifikovat konkrétní postupy, které učitelé volí ve vztahu k žákovské chybě, k níž dochází při interakci s celou třídou. Jedná se o specifickou situaci, protože žák se chyby dopouští před 
svými spolužáky, takže každý účastník výuky je s chybou seznámen a může na ni reagovat. Daný moment tedy na učitele klade požadavky, které se následně promítají do způsobu práce s chybou. Vymezeny byly celkem čtyři postupy, které se odlišují svým cílem a také tím, k jaké úrovni chybného výkonu se vztahují.

\section{1 Žákovská chyba}

Obecně můžeme chybu ve výuce dle Grassingera a Dresela $(2017$, s. 61) definovat jako chování jedinců, které se odchyluje od stanovené normy, zabraňuje dosažení určitého cíle či je učitelem považováno za nesprávné. Při identifikaci chyby se tedy jako podstatné jeví srovnání očekáváného výkonu s dosaženým výkonem či výsledkem činnosti, protože právě tato odchylka je hlavní charakteristikou chyby. Podobnou definici chyby představuje Slavík (1999, s. 71) či Pedagogický slovník (Průcha, Walterová, \& Mareš, 2003), kteř́ ji definují jako rozpor, jenž je odhalen v procesu hodnocení srovnáním s očekávaným vzorem. Chybu ve školní výuce tedy definuji jako výsledek žákovské činnosti, který se odlišuje od stanovené normy nebo je jako chybný určen učitelem. S termíny chyba, chybný výkon a chybná odpověd' pracuji jako se synonymy.

Jak ovšem upozorňují Harteis, Bauer a Heid (2012, s. 257), z hlediska vlastností dané chyby je podstatná osoba, která „deklaruje objekt pozorování jako chybný". Ve výuce je učitel důležitým činitelem, protože kromě samotné chyby určuje také vlastnosti, jež jsou chybnému výkonu přisuzovány. Dle Santagatové (2005, s. 492) je patrné, že připisované charakteristiky se mohou $\mathrm{v}$ čase proměňovat a vyvíjet, což vyplývá ze srovnání přístupu k chybě z hlediska behaviorální a konstruktivistické teorie. Behaviorální př́stup k chybě je založen na přesvědčení, že by se chybám ve výuce mělo předcházet, protože žáci se učí prostřednictvím správných řešení učebních úloh (Santagata, 2005, s. 492). V tomto tradičním pojetí má chyba negativní konotaci, protože slouží pouze jako akt kontroly a k ověřování výsledků, takže se tak stává určitým znakem neúspěchu (Kulič, 1971, s. 14). Obrat v tomto přístupu přineslo až konstruktivistické pojetí, jež vychází z přesvědčení, že učící se jedinec aktivně konstruuje své poznání okolního světa, které je založeno na selekci aktuálních zkušeností a jejich transformaci do vědomostních struktur (Pritchard \& Woollard, 2010, s. 8). Konstruktivismus pohlíží na jedince v celé délce jeho životní trajektorie, což znamená, že důležité jsou i každodenní zkušenosti, 
které předcházely samotnému učení ve výuce. Takto ustanovené vědomostní struktury označujeme jako miskoncepty, protože vznikají právě na základě vlastní zkušenosti a nereflektují vědecky sdílená vysvětlení (Steffe \& Gale, 1995, s. 15). Chyba má v tomto pojetí zásadní roli, protože umožňuje identifikovat podobu stávajících žákovských miskonceptů a reflexe chybného výkonu také přináší učiteli možnost, jak žákům napomoci v osvojování nových vědomostních struktur (Tulis, Steuer, \& Dresel, 2016, s. 14). Aktuálně je tedy chyba chápána jako samotný akt učení, jehož výsledky se dále zapojují do tohoto procesu jako jeho předpoklady (Kulič, 1971, s. 14-15). V rámci výzkumného šetření budu dále pracovat právě s konstruktivistickým pojetím chyby.

V pedagogické odborné literatuře je patrná snaha o vytváření kategorizací a typologií, které mohou chyby třídit např́klad dle četnosti výskytu, nositele, informační využitelnosti či kognitivní úrovně (Starý \& Laufková, 2016). Z obecného hlediska můžeme žákovské chyby dělit na základě způsobu, jakým vznikají. Typologie představená Corderem (1981, s. 10) rozděluje chyby na dvě skupiny a vychází z kognitivního přístupu k osvojování cizího jazyka. Zaprvé se jedná o chyby ve výkonu. Tyto chyby je žák schopen sám opravit, protože vznikají nahodile například z důvodu únavy, přeřeknutí, kvality komunikace či nepochopení zadání apod. Druhou skupinu tvoří chyby kompetenční, které již vznikají na základě žákovy neznalosti. Jedná se o systematické chyby, které poukazují na nedostatečné osvojení či nepochopení učiva. Tyto chyby můžeme dále dělit podle úrovně kognitivního procesu, na jehož základě chyba vznikla. K rozdělení můžeme využít revidovanou Bloomovu taxonomii, která představuje hierarchické uspořádání kognitivních procesů a je také doplněna o znalostní dimenzi (Anderson \& Krathwohl, 2001). Z hlediska těchto procesů může žákovská chyba vzniknout v procesu zapamatování, porozumění, aplikace, analýzy, hodnocení a tvoření. Chybu také můžeme kategorizovat s ohledem na znalostní dimenzi, dle které můžeme rozlišit chyby ve znalosti faktů, konceptů, $\mathrm{v}$ procedurální znalosti a také $\mathrm{v}$ rámci znalosti metakognitivní (Hudecová, 2004, s. 277). Na chyby je také možné nahlížet v kontextu konkrétních oborových didaktik. Při jazykovém vzdělávání můžeme jazykové chyby kategorizovat na základě dílčích jazykových systémů. Jak upozorňuje Jelínek (2001), rozlišit můžeme např́íklad chyby ve slovní zásobě, chyby ortografické, morfologické, chyby ve výslovnosti, chyby syntaktické či lexikální. 


\section{Učitelská práce s žákovskou chybou}

Učitel se ve výuce nevěnuje pouze opravování žákovských chyb, ale také žákům ukazuje způsoby, jak s chybou pracovat a jak s ní během výuky zacházet (Matteucci, Corazza, \& Santagata, 2015). Patrné ovšem je, že učitelé mohou k chybě přistupovat různým způsobem. Souhrn učitelských aktivit, které se vztahují k chybě, můžeme definovat jako tzv. error management (Tulis, 2013, s. 57). Mezi tyto aktivity zahrnujeme např́klad ignorování chyby, kritiku studenta, posměch, či naopak zdůraznění potenciálu chyby pro učení. Error management proto vzhledem k českému odbornému diskurzu definuji jako učitelskou práci s chybou, jež zahrnuje celou řadu konkrétních aktivit a postupů, které učitel ve výuce realizuje ve vztahu k žákovské chybě. Postupy vzhledem k výzkumnému šetření představují konkrétní ustálené vzorce chování, které učitelé $\mathrm{v}$ rámci práce s chybou realizují. Jednotlivé postupy můžeme rozdělit dle toho, zda se vztahují k afektivní nebo kognitivní rovině žákovské chyby (Zander, Kreutzmann, \& Wolter, 2014, s. 207). Nejdřrive bude pozornost věnována rovině afektivní a následně kognitivní.

První oblast učitelské práce s chybou se vztahuje k afektivní rovině chybného výkonu. $V$ př́padě chyby se podstatným stává sociální rozměr, protože její výskyt může pro žáka představovat negativní zkušenost, což se odvíjí od osobnostních charakteristik a také od situačních aspektů, jako je např́íklad podoba sociálních norem v dané tř́dě (Tulis et al., 2016, s. 15). Zaprvé může být chyba žákem vnímána jako určité selhání, jež je doprovázeno negativními pocity. Zadruhé může výskyt chyby vzbuzovat negativní reakce spolužáků, jež směřují k chybujícímu a mohou mít například podobu posměchu. Negativní důsledky chybného výkonu jsou také příčinou obav žákủ, že budou ve výuce chybovat. Učitelé mohou realizovat kroky, které strach z chybného výsledku u žáků podporují, či mu naopak zabraňují. Těmito postupy formují význam chyby a ovlivňují klima pro práci s chybou v dané školní třídě. Tzv. error climate učitelé ovlivňují například tím, že dávají žákům najevo svou toleranci k chybným výsledkům, věnují se chybám během výuky, či naopak projevují posměch nebo žáka kvůli chybě poníží (Steuer \& Dresel, 2015, s. 263-264). Důležité také je, zda učitel toleruje negativní reakce spolužáků, či naopak vůči nim projevuje nesouhlas. $\mathrm{Z}$ pohledu účastníků výuky tedy může klima pro práci s žákovskou chybou nabývat pozitivní nebo negativní podobu.

Druhá oblast učitelské práce se vztahuje ke kognitivní rovině chyby. Jedná se o způsob, jak učitel využívá chybu na podporu žákovského učení v rámci 
výuky. Jakmile dochází $\mathrm{k}$ řešení chyby formou opravy během komunikace, můžeme hovořit o tzv. konverzační opravě (Zeman, 2013). Nejdříve je iniciována oprava, kterou může provést učitel či chybující žák. Dále následuje samotná oprava, která může být provedena učitelem, jiným žákem či žákem, který se chyby dopustil. $\mathrm{V}$ tomto ohledu můžeme rozlišit opravy gramatické, které se vztahují například k chybám morfologickým či fonologickým, a opravy významu, jež si kladou za cíl „zkvalitnit významový obsah“ dané promluvy (Zeman, 2013, s. 86).

Detailnější pohled na práci s chybou nabízí Kulič (1971, s. 100), který vymezil její základní fáze. Jakmile se chyba ve výuce vyskytne, tak by měla být učitelem detekována explicitním upozorněním. Následně dochází k identifikaci chyby, kdy je určen její charakter. Třetí fáze se vztahuje k interpretaci chyby, ve které učitel uděluje význam chybě tím, že ji uvádí do širšího kontextu učiva, vysvětluje žákům důvody jejího vzniku a vysvětluje její potenciál pro budoucí učení. Proces intepretace zahrnuje složitou zpětnovazební činnost (Křivohlavý \& Mareš, 1995, s. 100). Celý postup je zakončen korekcí chyby, tedy její opravou. Daný způsob řešení chyby můžeme definovat jako způsob dialogický, protože žáka informuje o chybě a dává mu možnost využít poskytnuté informace pro vlastní učení (Kosíková \& Černá, 2013, s. 378). Opakem je tzv. direktivní způsob, jenž je založen jen na samotném aktu opravy, který ale žákovi nepřináší žádné užitečné informace pro jeho učení.

Učitelovu práci s chybou ovšem můžeme dále rozložit na konkrétní aktivity, kterých můžeme ve výuce vypozorovat celou řadu, jak potvrzuje výzkum realizovaný Tulisovou (2013) ve výuce matematiky, němčiny a ekonomiky. Nejfrekventovanější reakcí na chybu je udělení prostoru pro opravu samotnému chybujícímu žákovi, které může být také doprovázeno poskytnutím většího množství času na hledání správné odpovědi. Učitel v tomto př́ípadě zopakuje otázku nebo žákovi poskytne nápovědu, která usnadní hledání správné odpovědi. Druhou nejčastěji realizovanou činností je oprava chyby samotným učitelem. Zatřetí se učitelé uchylují k tomu, že jakmile žák odpoví na jejich otázku špatně, tak ji pouze přesměrují na jiného žáka, který dostane př́ležitost pronést správnou odpověd. Častým řešením chyby je také diskuze celé třídy nad hledáním správného řešení. Již minimálně se v reakci na chybu objevují činnosti, které mají charakter posměchu, ponížení žáka či projevu zklamání. Ojediněle se ovšem také objevují situace, ve kterých učitel upozorňuje na přínos chyby a zdůrazňuje její potenciál pro žákovské učení. 


\section{Metodologie výzkumného šetření}

Výzkumné šetření se zabývá postupy, které učitelé volí ve vztahu k chybě při interakci s celou trrídou. Jedná se o chybu, ke které dochází ve specifickém kontextu, protože žák chybuje před všemi účastníky výuky, takže každý má možnost reagovat. Stejně tak mají žáci dále možnost sledovat reakci učitele na vzniklou chybu. Šetření se zabývalo těmi postupy, jejichž volbu jsou učitelé schopni reflektovat. $Z$ tohoto důvodu budou při prezentaci výsledků využita data z pozorování výuky a také rozhovory s učiteli. Data z pozorování prezentují konkrétní postupy, které učitelé realizují, a data z rozhovoru reflektují jejich pohled na to, že tak činí. Výzkumná otázka tedy zní: Jaké postupy učitelé volí ve vztahu k žákovské chybě při interakci s celou tř́idou?

\subsection{Zkoumaný vzorek a metody sběru dat}

Výzkumné šetření bylo uskutečněno v rámci projektu GAČR Vztah mezi charakteristikami výukové komunikace a vzdělávacími výsledky žákủ (GA17-0364S). Sběr empirických dat byl realizován v hodinách českého jazyka ve vybraných tř́́dách devátého ročníku základních škol a měl kvantitativní a kvalitativní fázi. V rámci kvantitativní fáze, která probíhala od listopadu 2017 do ledna 2018, probíhalo strukturované pozorování ve 32 třídách na 21 školách a vzorek byl tvořen celkem 639 žáky (Tabulka 1). V každé třídě byly pozorovány dvě vyučovací hodiny, během kterých byl prostřednictvím tabletů zaznamenáván čas a charakter promluv všech účastníků výuky. Kvalitativní fáze, ze které vychází tato studie, probíhala od února do května 2018. V této části probíhal sběr dat ve čtyřech devátých třídách záměrně vybraných z kvantitativní fáze.

Tabulka 1

Přehled zkoumaného vzorku

\begin{tabular}{|c|c|c|c|c|c|c|}
\hline \multirow{2}{*}{ Škola } & \multirow{2}{*}{ Učitel } & \multirow{2}{*}{$\begin{array}{l}\text { Délka } \\
\text { praxe }\end{array}$} & \multirow{2}{*}{$\begin{array}{l}\text { Počet žáků } \\
\text { ve třídě }\end{array}$} & \multicolumn{3}{|c|}{ Počet videozáznamů } \\
\hline & & & & Mluvnice & Sloh & Literatura \\
\hline Maloměstská & Beata & 13 & 32 & 2 & 3 & 1 \\
\hline Městská & Daniela & 15 & 13 & 1 & 1 & 4 \\
\hline Venkovská I & Aneta & 4 & 26 & 2 & 1 & 3 \\
\hline Venkovská II & Chantal & 2 & 23 & 1 & 1 & 4 \\
\hline
\end{tabular}

Z důvodu zajištění anonymizace jsou v tabulce u učitelů i názvů škol použity pseudonymy. Stejně tak jsou v případě prezentace výsledků pseudonymy 
označeni všichni žáci, jejichž zákonní zástupci souhlasili s účastí na výzkumném šetření.

Pro realizaci výzkumu byl zvolen kvalitativní přístup, jenž umožňuje komplexní uchopení určitého fenoménu v jeho reálném kontextu (Yin, 2011, s. 7-8). Protože se šetření věnuje žákovské chybě z hlediska výukové komunikace, je pozornost věnována vzájemným interakcím mezi učitelem a žáky. Předpokladem pro tento přístup je tzv. sociokulturní teorie, která poukazuje na důležitost interakce a jazyka v rozvoji kognitivních funkcí žáka (Tůma, 2017, s. 25) a také konstruktivismus, který umožňuje pohlížet na chybu jako na př́ležitost k učení (Borasi, 1994, s. 199). Vzhledem k vymezeným východiskům a zkoumanému problému jsem zvolil přístup etnometodologické konverzační analýzy pro analýzu vyučovacích hodin, zatímco $\mathrm{k}$ rozboru rozhovorů s učiteli bylo přistupováno prostřednictvím zakotvené teorie. Základní koncept etnometodologie, ze které konverzační analýza vychází, představuje dle Hendla (2005, s. 88) tzv. dokumentární interpretování, jež spočívá v identifikaci určitých latentních vzorců, které je možné rozpoznat prostřednictvím jejich jevových vyjádření. Jednu z hlavních technik zkoumání produktů a procesů sociálního jednání představuje „podrobné zkoumání komunikačních technik“ (Hendl, 2005, s. 89.). Konverzační analýza v tomto ohledu výzkumníkovi umožňuje objevit a popsat strukturu konverzace a činnosti, kterými se interakce odehrává prostřednictvím komunikačních výměn (Wooffitt, 2005, s. 8). Dle Tůmy (2016, s. 426) dochází na základě analýzy vybraných sekvencí $\mathrm{k}$ abstrakci obecnějších zákonitostí. Jak upozorňují Heritage a Clayman (2011, s. 35), výuková komunikace představuje institucionální konverzaci, protože se odehrává v předem daném kontextu a směřuje k určitému cíli, což ovlivňuje její strukturu a podobu komunikačních výměn. Analýza tak výzkumníkovi odkrývá určité mechanismy, které již mohou představovat postupy či způsoby jednání účastníků výuky. Z hlediska zakotvené teorie byla pro rozbor rozhovorů využita metoda otevřeného kódování, která umožňuje identifikovat latentní kategorie v podobě konstruktů, jež stojí za určitým chováním či událostí (Hendl, 2005, s. 245).

Pro sběr empirických dat byly vybrány dvě výzkumné metody, protože triangulace výzkumných metod umožňuje uchopení zkoumaného problému z většího množství perspektiv, což také podporuje validitu a reliabilitu zjištěných výsledků (Švařriček \& Šed’ová, 2007, s. 204). Zaprvé se jedná o metodu pozorování. Ze všech pozorovaných vyučovacích hodin (celkem 24) byly pořízeny videozáznamy na dvě kamery, které byly orientovány na žáky 
a učitele. Vzniklé videozáznamy byly následně přepsány dle transkripčních pravidel vymezených Ten Havem (2007). Transkripční značky jsou vysvětleny v př́loze. Videozáznamy byly pořízeny a přepsány týmem výzkumníků řešících projekt GAČR. Následně proběhla analýza přepisů, která již byla realizována samotným autorem. Druhou metodu představovaly polostrukturované rozhovory s otevřenými otázkami. S každým učitelem proběhl jeden rozhovor zaměřený na práci s chybou ve výuce. Rozhovor byl realizován, přepsán i analyzován autorem studie. Rozhovory probíhaly v průběhu sběru dat a vztahovaly se k tomu, jakým způsobem učitelé ze svého pohledu s chybou pracují a jaké si myslí, že volí postupy vzhledem k určitým žákům, situacím apod. Rozhovor se nevztahoval ke konkrétním situacím z videonahrávek.

\subsection{Analýza dat}

V případě dat z výuky byla uplatněna metoda konverzační analýzy, zatímco v př́ípadě rozhovorů bylo pro analýzu zvoleno otevřené kódování, jež spočívá v rozložení datového materiálu na kódy, které jsou následně sdružovány do kategorií, jež tvoří základní linii interpretace (Harding, 2013, s. 93). Analýza probíhala ve dvou na sebe navazujících krocích a pro kódování byl použit počítačový program Atlas.ti, který umožňuje kódování datového materiálů (Friese, 2014). Při analýze byla použita strategie analytické indukce, která spočívá v hledání jevů či případů, které se v pozorované skutečnosti opakují (Bryman, 2012, s. 566). Zjištěná pravidelnost následně umožňuje postulování hypotézy, která se vztahuje k výzkumné otázce.

Nejprve proběhla analýza čtyř přepsaných rozhovorů zaměřených na práci $\mathrm{s}$ chybou. Při otevřeném kódováním rozhovorů vznikl výčet postupů, které učitelé dle svých slov realizují během výuky. $Z$ tohoto výčtu byly vybrány ty výpovědi, které se vztahují k chybě, ke které dochází při interakci s celou tř́idou. Na základě literatury byly následně postupy rozděleny podle toho, zda se vztahují k afektivní či kognitivní rovině chyby. Druhá fáze již představovala konverzační analýzu a zaměřila se na pořízené videozáznamy vyučovacích hodin. Z hlediska analýzy budu komunikační akty označovat jako repliky, které definuji jako „každý řečový úsek, na jehož konci je místo relevantní pro vystřídání mluvčích" (Nekvapil \& Havlík, 2007). Promluvu definuji jako „řečovou jednotku, která tvoří relativně samostatný a uzavřený obsahověsémantický celek s konkrétní komunikační funkcí a souvislou strukturou“ (Jelínek, 1984, cit. podle Hoffmanová, 2017). Prvním krokem při analýze vyučovacích hodin byla identifikace sekvencí, ve kterých se vyskytla žákovská 
chyba. Stanoveny byly celkem dva indikátory, jež určovaly žákovskou chybu. Zaprvé byla nesprávná žákovská odpověd' určena tím, že se odchylovala od předem stanovené a očekávané normy či cíle (Grassinger \& Dresel, 2017, s. 61). Druhým indikátorem bylo určení odpovědi jako nesprávné samotným učitelem prostřednictvím repliky či neverbálního signálu. Vymezené sekvence s chybným výkonem byly dále analyzovány z hlediska obsahu jednotlivých promluv vzhledem ke kontextu dané situace a ostatním replikám. Na základě analýzy byly vybrány celkem čtyři postupy.

\section{Výsledky výzkumného šetření}

Na základě empirických dat byly vymezeny celkem čtyři postupy, které učitelé volí vzhledem k žákovské chybě. Nejdříve se zaměřím na ty, které představují způsob reakce na chybnou odpověd' v odlišných výukových situacích. Následně představím zbylé dva postupy, které učitel realizuje před samotnou chybou a směřují zejména $k$ afektivní rovině chybného výkonu.

\subsection{Adaptivní reakce na chybu}

První vymezený postup představuje zpo̊sob, kterým učitel reaguje na chybu, jež se vyskytne během výukové komunikace. Reakce je charakterizována jako adaptivní, protože jejím cílem je přizpůsobit se chybné odpovědi konkrétního žáka a využít ji na podporu učení. $\mathrm{Z}$ hlediska výukové komunikace se učitel žákovské chybě přizpůsobuje prostřednictvím zpětné vazby, která také žákovskou odpověd’ dále rozvíjí, jak dokazuje ukázka 1:

Ukázka 1

Tématem dané části hodiny je procvičování v určování vět hlavních a vedlejších. Následně žáci určují také charakter věty vedlejší. Jednotlivé př́klady řeší postupně žáci, kteř́ jsou cíleně vyvolávání učitelkou.

1 Ž Tereza: netušili, jak jak to udělat (.) ((čte ze sešitu))

2

3 U Aneta:

4 Ž Tereza: druhá věta [vedlejší]

$5 \mathrm{U}$ :

[dobře.]

6

$7 \mathrm{U:}$

8

9

10 Ž Tereza: =koho co ((podívá se na učitelku))

$11 \mathrm{U}: \quad$ netušil. (.) KOHO CO. (.) ((pohybuje rukou dle slabik)) 
12 přesně tak. jo? koho co netušil.

13 a když se ptám koho co pádovou otázkou,

14 tak je to?=

15 Ž Tereza: =tak je to podmět- ((podívá se na učitelku))

$16 \mathrm{U}: \quad$ tak je to?

17 Ž Tereza: předmětná

$18 \mathrm{U}: \quad$ predmětná jo ((zdůrazní rukou))

19 <pádová otázka kromě prvního pádu>

20 to je podmětná> jinak je to předmětná. jo? <netušil koho co>

21 pozor na to jak to je to je hodně

22 to může být i způsobová to na to pozor.

V úvodu sekvence odpovídá žákyně na určení věty hlavní a vedlejší. Žákyně pronáší část odpovědi, na kterou učitelka verbálně reaguje pozitivně (ř. 3 a 5). Při určení charakteru věty vedlejší ovšem v odpovědi dochází k chybě, kterou učitelka signalizuje verbálně upozorněním: „Pozor, pozor.“ (ř. 7). Promluva učitelky dále obsahuje návodnou otázku, která se vztahuje k chybě (ř. 8) a jejímž cílem je podpořit žákyni v hledání správné odpovědi tím způsobem, že směřuje k určitému mezikroku, který vede ke správnému výsledku. Danou repliku můžeme označit jako tzv. uptake, protože představuje zpětnou vazbu, která si klade za cíl rozvinout žákovskou odpověd' (Chin, 2006). Cílem této zpětné vazby je navést žákyni $\mathrm{k}$ tomu, aby dokázala nalézt správnou odpověd'. Další replika (ř. 9) představuje nápovědu, jež má žákyni pomoci při hledání správné odpovědi. Na doplňující otázku žákyně odpovídá správně (ř. 10). Učitelka podává pozitivní zpětnou vazbu a pokládá další otázku, která si klade za cíl rozvoj žákovské promluvy, takže může být označena znovu jako uptake (ř. 13 a 14). Při odpovědi ovšem opakovaně dochází k chybě (ř. 15). Na nesprávnou odpověd' v tomto př́ípadě učitelka již reaguje rozdílným způsobem, protože nedochází ke snaze rozvinout žákovskou promluvu, ale následuje pouze zopakování otázky, které žákyni poskytuje další možnost pronést správnou odpověd'. Jak dokazuje replika na ř. 17, žákyně využívá možnost opravy a pronáší odpověd' bez chyby, což učitelka potvrzuje (ř. 18). Dále také přidává vysvětlení daného problému pro všechny žáky a upozorňuje na možný problém, který by v tomto učivu mohl nastat.

Širší kontext, ve kterém se přizpůsobivá reakce může odehrát, představuje procvičování v rámci mluvnice, jež umožňuje řešit použití gramatických pravidel, takže správné odpovědi mají předem jasně stanovenou podobu. To dává učiteli možnost žákům poskytnout podporu prostřednictvím zpětné 
vazby, pokud se chyby dopustí, protože je zřejmý cíl, ke kterému mají žáci dojít. Z hlediska výukové situace se přizpůsobivá reakce objevuje v př́ípadě, kdy je učivo $s$ žáky procvičováno. V této části hodiny mají pro učitele chybné odpovědi důležitý význam, protože mohou odhalit př́padné neporozumění učivu u konkrétního žáka. Aby učitel mohl identifikovat př́činu chyby a umožnit žákovi opravu, využívá tzv. uptake, který může představovat přeformulovanou nebo návodnou otázku (Chin, 2006). Použití daného postupu v podobě zpětné vazby, která rozvíjí žákovskou odpověd, volí učitelé se záměrem dovést konkrétního žáka ke správné odpovědi, jak upozorňuje učitelka Beata: „To se jako snažím, že chci odpověd’ tady od toho žáka. Až když to je fakt neúnosné a vidím, že z něho nic nedostanu, přestože položím nějakou návodnou otázku, tak pak se ptám ostatních." Jak z ukázky vyplývá, použití tzv. návodných otázek umožňuje učitelce podpořit v učení žáka, který se chyby dopustil. Ukázka číslo 1 ovšem dokazuje, že součástí návodných otázek může být také poskytnutí druhé šance, kdy učitelka žákovi poskytne další možnost na správnou odpověd’ předtím, než vyvolá jiného žáka. Aby žákovská chyba měla př́ínos pro všechny žáky, učitelka ji využívá jako podklad pro vysvětlení daného pravidla. Chyba se tak stává signálem, že se může jednat o problémové učivo, takže dochází k podrobnějšímu vysvětlení pro celou třídu.

\subsection{Relativizace chybné odpovědi}

Druhým postupem, který učitelé volí při výskytu chyby, je udělení prostoru pro vysvětlení způsobu daného řešení. Učitel tedy danou odpověd' neoznačuje kategoricky za nesprávnou, ale konfrontuje ji se svým vlastním názorem a dává žákům možnost vysvětlit vlastní řešení, čímž chybnou odpověd' relativizuje. Danou situaci ilustruje ukázka 2:

\section{Ukázka 2}

Tématem dané situace je řešení vztahu mezi pojmy pomoc a zdroj. Učitelka se ptá, který pojem je nadřazený druhému.

1 U Beata: je (.) když si vezmeme slovo nadřazené podřazené

2 tady tahle pomoc a tady ten zdroj, ((ukazuje na tabuli))

3 co by z toho bylo jako nadřazené? (2) ((stojí u tabule))

4 Ž Standa: zdroj. (2)

$5 \mathrm{U:} \quad$ proč? (1)

6 Ž Standa: proto.

$7 \mathrm{U} \quad$ proto nestačí. nejste na [prvním stupni.]

8 Ž Franta:

[LOGICKÁ ÚVAHA] 
$9 \mathrm{U}: \quad$ mně to není logické. vysvětli mi to. já to nechápu. (3)

10 proč je zdroj nadřazený pomoci? (1)

11 já to zrovna vidím naopak.

12 Ž Martin: zdroje jsme si schopni najít

13 a pomoc hledáme v úzkém z-. ((usmívá se)) (2) tak ne. (1)

$14 \mathrm{U}: \quad$ děcka ten zdroj. čeho se týká ten zdroj? ((posune se ke katedře)) (.)

15 když máte zadané téma? tak hledáte zdroje k tomu tématu.

16 ale co může být pomoc? (.) to nemusí být $\mathrm{k}$ tomu tématu přece=

17 Ž Martin: =pomoc kom-, ne (prezentaci).= ((gestikuluje))

$18 \mathrm{U}: \quad$ = přesně tak a proto je to pro mě širší tady tenhle pojem.

19 protože tady ta pomoc může být (.) nebo ta zkušenost. (.)

20 už mám <zkušenost $\mathrm{z}$ jiného předmětu už vím jak to říct>

21 dostal jsem minule pětku už vím čeho se vyvarovat.

22 tohle je mnohem širší. zdroj je na konkrétní věc a

23 já o něčem můžu vědět něco víc. (.) něco míň. (.)

$24 \quad$ ale tohle je mnohem širší. jo?

25 takže proto tady to to chápu tímto způsobem. (.)

26 ale nenutím vás to tak chápat.

V úvodu ukázky se učitelka ptá, jaký je rozdíl mezi zdrojem a pomocí z hlediska jejich podřazenosti či nadřazenosti. Žák odpovídá, že nadřazené slovo je zdroj (ř. 4). V následující replice učitelka rozvíjí žákovskou odpověd’ tím, že se ptá na zdůvodnění odpovědi. Žák odpovídá, že výsledek určil logickou úvahou (ř. 8). Následuje ovšem promluva učitelky, která danou odpověd' zpochybňuje tím způsobem, že ji konfrontuje se svým názorem. Učitelka v tomto kroku naznačuje, že se jedná o její postoj prostřednictvím tvrzení „mně to není logické" (ř. 9), a žádá o vysvětlení daného postoje. V replice č. 11 také žákům sděluje vlastní názor - „já to zrovna vidím naopak“. Nedochází tedy k explicitnímu označení dané odpovědi jako chybné, ale ke konfrontaci s názorem učitelky, což učitelka dává žákům najevo. Replika na řádcích 12 a 13 představuje snahu o vysvětlení, na kterou učitelka navazuje tím, že se snaží přeformulovat otázky, které by lépe mohly ilustrovat její vlastní postoj. Následně dochází k odpovědi žáka (ř. 17), na kterou již učitelka reaguje pozitivním přijetím (ř. 18). Učitelčina promluva je dále tvořena vysvětlením vlastního názoru, což je explicitně také zdůrazněno - „takže proto tady to chápu tímto způsobem“ (ř. 25). V závěru repliky také dochází k upozornění, že se jedná jen o vlastní názor učitelky, takže žáci mohou mít na celý problém názor odlišný (ř. 26). 
Daný způsob reakce na nesprávnou odpověd' je volen zejména v př́ípadě, kdy otázka nemá pouze jednu správnou odpověd', takže žáci mají možnost obhájit svůj vlastní postoj. Vysvětlení vlastního postoje můžeme definovat jako vyšší kognitivní proces, který dle učitelky Daniely vyžaduje specifickou reakci: „Popravdě řečeno rozlišuji [úroveň kognitivních procesů] a u vyšších kognitivních procesů vůbec nikdy podle mě neříkám špatně. Že spíše jako ř́kám, pojd'me se zamyslet nad tím, rozebereme." Pokud je tedy na učitelskou otázku možné odpovědět vícero způsoby, nedochází k označení určitých odpovědí jako chybných. $V$ př́ípadě, že se odpověd' učiteli jeví jako chybná, volí možnost diskuze a dává žákům možnost obhájit vlastní názor. Učitel tento postup volí i v situaci, kdy je podoba odpovědi v rozporu $\mathrm{s}$ jeho názorem. Předpokladem pro relativizaci chybné odpovědi jsou také otevřené otázky, které umožňují větší množství odpovědí, jejichž správnost je možné podložit argumenty a obhájit je. Daný postup je také spojen s metodou diskuze, která dovoluje střet různých názorů, postojů či subjektivně vnímaných informací. Prostřednictvím relativizace učitel žákům dává najevo, že každá odpověd' může být správná, pokud je podložena argumenty, takže žáci se nemusí obávat zapojení, protože vždy mají možnost svůj postoj obhájit. Konkrétní způsob realizace tohoto postupu představuje upozornění, že daná odpověd' je považována za chybnou jen z pozice učitelova názoru. Tato snaha také vede $\mathrm{k}$ přímé podpoře participace, protože učitel po žácích požaduje vysvětlení jejich stanoviska, takže jim vytváří prostor pro zapojení. Učitel také své stanovisko žákům vysvětluje, čímž jim umožňuje seznámit se s jiným pohledem na daný problém a popř přehodnotit své stanovisko.

\subsection{Ochrana před chybnou odpovědí u vybraných žáků}

Předchozí činnosti byly učiteli realizovány v přímé návaznosti na chybnou žákovskou odpověd'. Ochrana před nesprávnou odpovědí ovšem představuje postup, prostřednictvím kterého učitelé záměrně chybným odpovědím u vybraných žáků předcházejí. Učitelé shodně tuto skupinu žáků označují jako žáky „slabší a jedná se o ty, kteří mají horší školní prospěch, jenž je zapříčiněn specifickými vzdělávacími potřebami či jinými důvody. Tito žáci mohou být ovlivněni negativními dopady, jež mohou představovat způsoby reakce spolužáků. Účelem této aktivity je nedemotivovat žáky tím, že by se dopustili chyby při snaze odpovědět na učitelskou otázku. Patrné tedy je, že ochrana před chybnou odpovědí se primárně vztahuje k afektivní rovině chyby, protože ji učitelé realizují právě s ohledem na sociální důsledky chyby. 
Způsob realizace této aktivity nastiňuje učitelka Aneta: „Vepředu sedí Tomáš a on se jako nehlásí vůbec, on nekomunikuje... A tak spíš to dělám tak, že on sedí přede mnou a když vidím, že to má třeba doplněné správně, tak ho vyvolám, aby si mohl správně říct, jak to doplnil, a pak ho vlastně pochválím, že to řekl správně." Snaha o prevenci je zde založena na skutečnosti, že vybraný žák se vyhýbá zapojení do výukové komunikace. Učitelka se ho proto snaží cíleně zapojit tím způsobem, že ho vyvolá na otázku, o které je přesvědčena, že na ni bude schopen odpovědět pouze správně. Důležitým aspektem je také umístění žáka ve tř́́dě, které učiteli před vyvoláním umožňuje vizuální kontrolu. Ochrana před nesprávnou odpovědí ve svém důsledku také umožní pochválení žáka před celou třídou za to, že na učitelskou iniciaci odpověděl správně, což může vést ke zvýšení motivace pro příští zapojení do komunikace. Jak dokazují další učitelé zapojení do výzkumu, způsob ochrany před nesprávnou odpovědí také mủže představovat vyvolání na bezpečné téma, které má větší množství odpovědí, nebo využití speciální úlohy. „Dělám s nimi kreativní abecedu, že mají napsat pojmy. Karel Čapek a mají napsat ke každému písmenku pojem, který je napadne ke slovu Karel Čapek. A ne samozřejmě všichni mají všechno, ale obcházím a jdu se podívat na ty nejslabší, abych je vyvolala." Příklad učitelky Beaty dokládá, že snaha o prevenci před chybnou odpovědí může mít systematickou a cílenou formu učební úlohy.

Ačkoliv je pozornost v pedagogickém výzkumu věnována zejména aktivitám, které směřují k využití chyby pro učení, je patrné, že učitelé si uvědomují i její afektivní rovinu, která má ve svém důsledku vliv na určité žáky ve tř́dě. Učitelé tento negativní charakter chyby reflektují zejména u skupiny žáků, u kterých se cílem stává jejich ochrana. Patrné je, že význam chyby je ovlivněn i charakteristikami žáků, kteří se chyb dopouští. Zatímco u dobře hodnoceného žáka může být chyba podkladem pro další činnost ve výuce, tak na „slabého“ žáka může chyba mít negativní vliv. Učitelé se tedy snaží, aby tito žáci odpovídali pouze správně a bez chyb. Ačkoliv chybná odpověd' poskytuje možnost, jak podporovat žákovské učení, tak v tomto případě je její přínos preventivně upozaděn na úkor sociálního rozměru.

\subsection{Minimalizace negativního pojetí chyby}

Poslední vymezený postup je definován jako minimalizace negativního pojetí chyby a popisuje snahu učitele cíleně a záměrně formovat význam chyby v sociálním prostředí školní třídy. Chyba může být v prostředí třídního 
kolektivu vnímána negativním způsobem, což znamená, že se jí žáci snaží vyhnout, a může také docházet k negativním reakcím, pokud se chybná odpověd' ve výuce vyskytne. Minimalizace negativního pojetí zahrnuje celkem dvě činnosti, jejichž cílem je ovlivnit vnímání chybného výkonu mezi žáky.

Zaprvé se učitel snaží minimalizovat pojetí nesprávné odpovědi prostřednictvím explicitních upozornění, že chyba nepředstavuje nic negativního. Danou situaci ilustruje ukázka 3:

Ukázka 3

$V$ dané části hodiny probíhá diskuze o vesmíru. Žáci mají vysvětlit, co znamená věta „Vesmír nemá žádnou nadčasovou geografii“.

1 U Daniela: zkuste zkuste to nějak vysvětlit, 2 jakýmkoliv způsobem tu větu. (4)

3 když se netrefíte (.) tak se nic neděje že jo ((prochází mezi žáky)) (10)

4 Ž Denis: já nevím ((mluví k učitelce, krčí rameny))

$5 \quad$ kdybych aspoň chápal. (2) já to nechápu.

$6 \mathrm{U}: \quad$ ((zasměje se a přichází k žákovi))

7 U: $\quad$ co nechápeš? ((mluví tiše a sklání se k žákovi))

8 Ž Denis: ty prostory. (2) jak může mít vesmír ( )?

$9 \mathrm{U}: \quad$ ZAJÍMAVÉ, že? ((směje se a odchází před tabuli)) (5)

$10 \mathrm{U}: \quad$ tak. kdo by chtěl odpovědět $($.

11 na to (.) co je to rozpínavost vesmíru?

12 jak byste to vlastními slovy vysvětlili? Libore třeba? (2)

13 Ž Libor: já jsem tam napsal čím dále jsou galaxie od sebe.

14 tím rychleji se pohybují. (.) a vzdalují. (2)

$15 \mathrm{U}: \quad$ máte něco podobného? Co tam máte? Dane?

16 Ž Denis: no takže. galaxie ve vesmíru se ( )=

$17 \mathrm{U}: \quad=$ =ehm. (2) ta-tady to bylo asi celkem jasné::

18 to tam bylo vysvětlené hezky. Vždycky si můžete představit

19 ten balónek na který si nakreslíte ty tečky. (.) tak

20 a co teda znamená věta. vesmír nemá žádnou nadčasovou geografii?

21 <Ona je poměrně složitá.> ee (.) zkusili byste někdo vysvětlit? (3)

22 to nevadí když (.) když to nebude dobře. (3)

23 cokoliv? Já vím že tam něco máte ((usmívá se a jde k lavici))

24 jenom nechcete mluvit.

25 Ž David: já-=

26 U: = no Davide? ((podívá se na žáka))

27 Ž David: já to mám poškrtaný::. já tam nic nemám. 
V úvodu sekvence je patrné, že učitelka explicitně upozorňuje žáky, že se nemusí obávat nesprávné odpovědi, pokud se zapojí do komunikace (ř. 3). Tato výzva je součástí učitelské iniciace, která má formu otázky určené pro celou tř́́du. Snaha o minimalizaci je tedy součástí konkrétní otázky, která má charakter tzv. open invitation, protože umožňuje zapojení všech žáků do komunikace (Willemsen et al., 2018). Cílem je podpořit žáky, kteří si nemusí být svou odpovědí jistí či se obávají, že jejich odpověd' nebude správná, aby se zapojili do výukové komunikace. Na danou iniciaci reaguje žák, který učitelku informuje o tom, že nerozumí tématu, ke kterému se otázka vztahuje (ř. 5). Na tuto repliku navazuje otázka ohledně toho, čemu žák konkrétně nerozumí (ř. 8). Explicitní upozornění na neporozumění učivu před všemi spolužáky můžeme reflektovat jako projev charakteristik daného prostředí. Je patrné, že na přiznání chyby $\mathrm{v}$ podobě nepochopení určitého problému nepřichází žádná negativní reakce ze strany spolužáků. Naopak, učitelka využívá ostatní žáky k tomu, aby se podíleli na samotném vysvětlení (ř. 10). Totožný postup minimalizace negativního pojetí chyby je patrný také v promluvě učitelky v závěru sekvence, kdy žáky upozorňuje, že nevadí, pokud jejich odpověd' bude chybná (ř. 22). Na tuto promluvu reaguje žák, který učitelce sděluje, že danou úlohu nevyřešil (ř. 27). Znovu dochází k tomu, že se žák dobrovolně přiznává, že nezná správné řešení. Minimalizace negativního pojetí je tedy uplatněna $\mathrm{v}$ rámci diskuze. Negativní pojetí chyby $\mathrm{v}$ žákovském kolektivu může způsobit, že se žáci vyhýbají zapojení do komunikace v případě nejistoty o správnosti své odpovědi. Pro učitele je v rámci diskuze primárně důležité zapojení žáků nehledě na správnost, což dávají explicitně najevo. Tento postup také dle výše uvedené ukázky plní ten efekt, že se žáci neostýchají přiznat, že neznají správné řešení či učivu nerozumí. K popírání a schovávání vlastních chyb dochází právě v těch třídách, ve kterých je chyba vnímána negativně (Seifried \& Wuttke, 2010, s. 149).

Další způsob, jak učitelé dosahují minimalizace negativního pojetí chyby, nastává v př́ípadě, kdy žáci reagují na chybnou odpověd' posměchem či jiným pro učitele nepř́ipustným způsobem. „V hodinách na začátku, když jsem je dostala, tak měli tendence se někomu smát. Ale já říkám: ,Nechte toho jako a nikdo se smát nebude.' Ř́kám: ,Chybovat může každej.' Tak oni se odnaučili jako nějak smát druhýmu." (učitelka Chantal). Chyba se ve výuce může stát zdrojem negativních reakcí, jež jsou směřovány k chybujícímu žákovi. Učitelé se ovšem žáky snaží vést $\mathrm{k}$ tomu, že chyba nepředstavuje nic negativního, takže na ni není možné reagovat daným způsobem. Účelem tohoto postupu 
je tedy nastavení určitých komunikačních pravidel a také ochrana žáků, kteří mohou být chybou stigmatizováni. Z ukázky vyplývá, že podoba komunikačních pravidel spojených $\mathrm{s}$ chybou se ve třídě může $\mathrm{v}$ čase proměňovat. Negativní reakce na chybný výkon se ve třídě objevuje, pokud učitel označuje dané chování jako přípustné či na něj žádným způsobem nereaguje. Jakmile ovšem začne docházet k signalizaci nesouhlasu s daným chováním, žáci se začnou chovat požadovaným způsobem. Přístup žáků k chybujícím spolužákům je tak silně ovlivněn učitelem, který ve školní třídě vytváří určité klima pro práci s chybou, které představuje součást celého třídního klimatu.

\section{Diskuze}

V učitelské práci s chybou, ke které dochází během interakce s celou třídou, můžeme vymezit určité postupy, jež učitelé realizují. Jak je ovšem patrné z výsledků šetření, postupy se mohou vztahovat k různým aspektům chybného výkonu a mohou plnit různé cíle. Ačkoliv je chybě často věnována pozornost z hlediska hodnocení (např. Slavík, 1999; Starý \& Laufková, 2016), učitelská práce s chybou také zasahuje do profesních činností učitele, které můžeme označit jako aktivizace žáků a jejich motivace či řízení učebních činností a jejich koordinace (Babiaková, 2012, s. 230). Na práci s chybou tedy můžeme nahlížet jako na komplexní činnost, která se skládá z postupů, jež žákovské chybě předcházejí či na ni navazují. Z hlediska zaměření postupů bylo využito dělení na rovinu afektivní a kognitivní, které vymezili autoři Zander a kol. (2014, s. 207). Ke kognitivní rovině se vztahují ty postupy, které chybu využívají na podporu žákovského učení a směřují k interpretaci a korekci chyby. K rovině afektivní zase řadíme ty postupy, které reagují na sociální aspekt chyby.

Dle Seifrieda a Wuttkeové (2010, s. 148) existuje řada empirických důkazů, že učitelé mají klíčovou roli při využití potenciálu chyby pro učení žáků. Autoři také vymezili základní dovednosti, které by učitel měl mít, aby mohl žáky při učení podporovat. Jedná se o znalost možných typů chyb, orientaci ve strategiích řešení chyb a důležitý je také konstruktivní př́ístup k chybám. $Z$ daného výčtu je patrné, že důraz je kladen zejména na kognitivní rovinu chybného výkonu. Z výsledků šetření ovšem vyplývá, že polovina realizovaných postupů se vztahuje právě k rovině afektivní. Jedná se o postupy označené jako ochrana žáků před chybnou odpovědí a minimalizace negativního pojetí chyby. Hlavním cílem těchto postupů je vytvořit ve výuce takové prostředí, 
ve kterém chyba není vnímána negativně, ale naopak jí je přisuzována konstruktivní role z hlediska žákovského učení. Steuerová (2015, s. 263) upozorňují, že klima pro práci s chybou v dané třídě je primárně ovlivňováno chováním učitele, na které navazuje chování žáků. Vymezené postupy tedy směřují $\mathrm{k}$ tomu, aby formovaly pozitivní prostředí pro práci s chybou, a to ve dvou rovinách. Zaprvé učitelé chrání určité žáky před negativními reakcemi spolužákủ. Zadruhé učitelé ubezpečují všechny žáky, at' se nebojí do výukové komunikace zapojit i přes riziko, že jejich odpověd' nebude správná. Postup nazvaný minimalizace chybné odpovědi podporuje zapojení žáků i v př́ípadě, že si nejsou jisti správností své odpovědi. Jak upozorňují Schleppenbach a kol. (2007, s. 144), je patrné, že tyto postupy předcházejí samotné práci $\mathrm{s}$ chybou a vedou k tomu, že žáci považují za běžné dopouštět se chyb a také o nich následně diskutovat.

Pro detailnější pochopení učitelských postupů spjatých s afektivní úrovní žákovské chyby je ovšem nutné vzít v úvahu i charakteristiky konkrétního žáka, který se chyby dopouští. Dle Babada (2005) je patrné, že učitelé se chovají rozdílným způsobem $\mathrm{k}$ žákům $\mathrm{s}$ rozdílnou úrovní výkonnosti. $\mathrm{V}$ tomto případě učitelé záměrně pracují s žáky, kteří dosahují horších výsledků, aby jim napomohli v participaci na výuce. Zapojení do výukové komunikace má pro tyto žáky důležitý benefit, protože participace napomáhá konstrukci poznatků a učení (Šed'ová \& Šalamounová, 2015, s. 77). V případě tohoto postupu je důležité, že jej učitelé realizují vzhledem k určité skupině žáků, což dokazuje, že práci s chybou nelze vnímat univerzálně, ale může se u určitých žáků proměňovat vzhledem $\mathrm{k}$ jejich charakteristikám. Ačkoliv tedy ignorování chyby či přesměrování otázky na jiného žáka mohou být vnímány jako způsoby, které neprospívají žákovskému učení (Tulis, 2013), pro učitele mohou plnit význam ochrany žáka před negativním dopadem chybného výsledku.

Při pohledu na vymezené postupy s označením adaptivní reakce a relativizace nesprávné odpovědi, které následují po chybě, je zřejmé, že učitelé svými reakcemi sledují různé výukové cíle. Adaptivní reakce je učiteli realizována $\mathrm{v}$ rámci procvičování učiva mluvnice. $\mathrm{V}$ tomto kontextu se chyba jeví jako důležitá, protože učiteli umožňuje identifikovat, zda bylo dosaženo vzdělávacího cíle v podobě osvojení určité látky, a informuje jej také o dosaženém žákovském výkonu (Kalová, 2018, s. 74). V př́padě relativizace chyby se jako cíl ovšem jeví vedení žáků k vysvětlení jejich stanoviska. Tento postup je zase uplatňován v případě, kdy otázka nemá jednu danou odpověd', takže může dojít k diskuzi učitele a žáků, která povede k argumentaci určitého postoje 
či stanoviska. Dle Zemana (2013, s. 86) tedy můžeme tento postup popsat jako opravu významu, protože dochází k úpravě obsahu či hledání obsahu výstižnějšího. Základním rozdílem mezi uplatňovanými postupy je samotné učivo, které konkrétní reakci umožňuje. Z hlediska kognitivních žákovských procesů ovšem oba dva postupy vedou k podpoře vyšších kognitivních procesů. Žáci v návaznosti na reakci učitele uplatňují analýzu, syntézu, aplikují či tvoří (Anderson \& Krathwohl, 2001). Vzhledem k aktivitě žáka můžeme oba postupy označit jako dialogické řešení chyby, protože analýza chyby a její korekce je aktivně prováděna žákem v dialogu s učitelem (Slavík, 1994, s. 125).

Za důležité části vymezených postupů můžeme označit zpětnou vazbu, kterou učitel poskytuje žákovi po výskytu chyby. Využití chyby pro žákovské učení spočívá právě ve způsobu zpětné vazby, který se může proměňovat. Jak upozorňují Šed'ová a Švařriček (2010, s. 82), během výuky může docházet k tzv. zamlčenému hodnocení, kdy učitel žákủm neposkytuje informace o jejich výkonu a výsledku. Daný mechanismus naopak zabraňuje využití chyby, avšak může mít přínos ze sociálního hlediska, protože daný výkon neoznačuje jako chybný. Roli zpětné vazby při práci s chybou tak můžeme vnímat jako klíčovou. Zpětnou vazbu, která obsahuje informace o úspěšnosti či neúspěšnosti, správnosti postupu a další informace zaměřené na podporu žáka, můžeme označit jako tzv. korektivní zpětnou vazbu (Hattie \& Timperley, 2007, s. 91).

Rozdělení jednotlivých postupů odkazuje na skutečnost, že učitelé v případě chyby reflektují její kognitivní i afektivní úroveň, což vede k využití různorodých postupů, které ovšem můžeme zahrnout pod učitelskou práci s chybou. Jak upozorňují Steuerová a kol. (2013, s. 196), pokud je chyba vnímána negativním způsobem, tak jsou i možnosti pro její využití během výuky poměrně omezené. Do jisté míry proto můžeme reflektovat skutečnost, že sociální rozměr předchází využitelnosti chyby pro učení. Postupy vybraných učitelů poukazují na to, že i ve vyučovací praxi se tyto roviny chyby prolínají a práci s chybou je nutné chápat jako komplexní proces. Přesto musíme upozornit, že v rámci příspěvku byla pozornost věnována pouze těm postupům, jejichž využití dokázali učitelé reflektovat prostřednictvím rozhovorů. Ve výuce ovšem existují i postupy a činnosti, které učitelé realizují bezděčně, aniž by si uvědomovali jejich použití. 


\section{Závěr}

Předložené výzkumné šetření se zabývalo postupy, jež učitelé realizují záměrně ve spojitosti s žákovskou chybou, ke které dochází v průběhu interakce učitele $s$ žáky. Cílem studie bylo navázat na výsledky zahraničního výzkumu, který se v posledních dekádách věnuje chybě zejména $\mathrm{z}$ hlediska učitelských reakcí, které ve výuce po chybě následují (Ingram, Pitt, \& Baldry, 2015; Santagata, 2005). Jak ovšem dokazují výsledky tohoto šetření, učitelé některé činnosti realizují ještě před samotnými chybami a také podobu těchto činností je nutné vnímat v širších podmínkách, které jsou tvořeny například tématem a cílem výuky či vlastnostmi žáka. Vymezeny byly postupy nazvané adaptivní reakce a relativizace chyby, které směřují k využití chyby na podporu učení. Zbývající postupy s označením ochrana žáka před chybnou odpovědí a minimalizace negativního pojetí chyby zase ovlivňují vnímání chyby v daném třídním kolektivu.

\section{Literatura}

Anderson, L. W., \& Krathwohl, D. R. (2001). A taxonomy for learning, teaching, and assessing: A revision of Bloom's taxonomy of educational objectives. New York: Longman.

Babad, E. (2005). Guessing teachers' differential treatment of high-and low-achievers from thin slices of their public lecturing behaviour. Journal of Nonverbal Behavior, 29(2), 125-134.

Babiaková, S. (2012). Komparácia profesijných činností slovenských, českých a pol'ských učitel'ov na primárnom stupni školy. Pedagogická orientace, 22(2), 222-242.

Borasi, R. (1994). Capitalizing on errors as „Springboards for Inquiry“: A teaching experiment. Journal for Research in Mathematics Education, 25(2), 166-208.

Bray, W. S. (2011). A collective case study of the influence of teachers' beliefs and knowledge on error-handling practices during class discussion of mathematics. Journal for Research in Mathematics Education, 42(1), 2.

Bryman, A. (2012). Social research methods. New York: Oxford University Press.

Corder, S. P. (1981). Error analysis and interlanguage. New York: Oxford university press.

Friese, S. (2014). Qualitative data analysis with ATLAS.ti. Thousand Oaks: Sage.

Grassinger, R., \& Dresel, M. (2017). Who learns from errors on a class test? Antecedents and profiles of adaptive reactions to errors in a failure situation. Learning and Individual Differences, 53, 61-68.

Harding, J. (2013). Qualitative data analysis from start to finish. Thousand Oaks: Sage.

Harteis, C., Bauer, J., \& Heid, H. (2012). Human fallibility. Dordrecht: Springer.

Hattie, J., \& Timperley, H. (2007). The power of feedback. Review of Educational Research, 77(1), 81-112.

Hendl, J. (2005). Kvalitativní výzkum: základní metody a aplikace. Praha: Portál. 
Heritage, J., \& Clayman, S. (2011). Talk in action: Interactions, identities, and institutions. Chichester: John Wiley \& Sons.

Hoffmannová, J. (2017). Institutciální dialog. In P. Karlík, M. Nekula, \& J. Pleskalová (Eds.), CzechEncy - Nový encyklopedický slovník češtiny. Dostupné z https://www.czechency.org/ slovnik/INSTITUCIONÁLNÍ DIALOG

Hudecová, D. (2004). Revize Bloomovy taxonomie edukačních cílů. Pedagogika, 54(3), 274-283.

Chin, C. (2006). Classroom interaction in science: Teacher questioning and feedback to students responses. International Journal of Science Education, 28(11), 1315-346.

Ingram, J., Pitt, A., \& Baldry, F. (2015). Handling errors as they arise in whole-class interactions. Research in Mathematics Education, 17(3), 183-197.

Jelínek, M. (2001). Co je to jazyková chyba? In K. Klímová \& H. Kneselová (Eds.), Profesor Hauser jubilující: sborník příspěvků ze semináře konaného 10. 4. 2001 při př́ležitosti 80. narozenin prof. PhDr. Přemysla Hausera, CSc. (s. 75-85). Brno: Masarykova univerzita.

Kalová, S. (2018). Úloha chyb, korektivní zpětné vazby a normy v cizojazyčné výuce s důrazem na výuku angličtiny. Pedagogická orientace, 28(1), 72-110.

Kosíková, V., \& Černá, K. (2013). Výzkum kvality informační funkce hodnocení ve středoškolské praxi. Pedagogika, 63(3), 372-393.

Křivohlavý, J., \& Mareš, J. (1995). Komunikace ve škole. Brno: Masarykova univerzita.

Kulič, V. (1971). Chyba a učení: funkce chybného výkonu v učení a v jeho řízení. Praha: Státní pedagogické nakladatelství.

Matteucci, M. C., Corazza, M., \& Santagata, R. (2015). Learning from errors, or not: An analysis of teachers' beliefs about errors and error-handling strategies through questionnaire and video. Dostupné $\mathrm{z}$ https://s3.amazonaws.com/academia.edu.documents/42369304/ Pre_print_Matteucci_Corazza_Santagata_Novascience_Chapter.ID_33975_7x10.pdf?AW SAccessKeyId=AKIAIWOWYYGZ2Y53UL3A\&Expires $=1537531031 \&$ Signature $=\mathrm{zPhsm} 8$ emMTbceQJhnG3HWQtbP\%2F8\%3D\&response-content-disposition=inline $\% 3 \mathrm{~B} \% 20 \mathrm{fi}$ lename\%3DLEARNING_FROM_ERRORS_OR_NOT_AAN_ANALYSIS.pdf

Nekvapil, J., \& Havlík, M. (2007). Replika v rozhovoru. In P. Karlík \& J. Plesková (Eds.), CzechEncy Nový encyklopedický slovník češtiny. Dostupné z https://www.czechency.org/slovnik/ STŘÍDÁNÍ REPLIK MLUVČÍCH V ROZHOVORU

Ondráková, J. (2014). Chyba a výuka cizích jazyků. Hradec Králové: Gaudeamus.

Pritchard, A., \& Woollard, J. (2010). Psychology for the classroom: Constructivism and social learning. New York: Routledge.

Průcha, J., Walterová, E., \& Mareš, J. (2003). Pedagogický slovník. Praha: Portál.

Santagata, R. (2005). Practices and beliefs in mistake-handling activities: A video study of Italian and US mathematics lessons. Teaching and Teacher Education, 21(5), 491-508.

Seifried, J., \& Wuttke, E. (2010). Student errors: How teachers diagnose and respond to them Empirical Research in Vocational Education and Training, 2(2), 147-162.

Schleppenbach, M., Flevares, L., Sims, L., \& Perry, M. (2007). Teachers' responses to student mistakes in Chinese and U.S. mathematics classrooms. The Elementary School Journal, 108(2), 131.

Slavík, J. (1994). Problém chyby v tvořivě výrazové výchově. Pedagogika, 44(2), 119-128.

Slavík, J. (1999). Hodnocení v současné škole: východiska a nové metody pro praxi. Praha: Portál. 
Slavík, J. (2003). Autonomní a heteronomní pojetí školního hodnocení - aktuální problém pedagogické teorie a praxe. Pedagogika, 54(1), 5-25.

Starý, K., \& Laufková, V. (2016). Formativní hodnocení ve výuce. Praha: Portál.

Steffe, L. P., \& Gale, J. E. (1995). Constructivism in education. Hillsdale: Lawrence Erlbaum.

Steuer, G., \& Dresel, M. (2015). A constructive error climate as an element of effective learning environments. Psychological Test and Assessment Modeling, 57(2), 262-275.

Steuer, G., Rosentritt-Brunn, G., \& Dresel, M. (2013). Dealing with errors in mathematics classrooms: Structure and relevance of perceived error climate. Contemporary Educational Psychology, 38(3), 196-210.

Šed'ová, K., \& Šalamounová, Z. (2015). Žákovská participace na komunikaci jako produkt interakcí mezi učitelem a žákem. Lifelong Learning - celoživotní vzdělávání, 5(3), 75-94.

Šed'ová, K., \& Švaříček, R. (2010). Zamlčené hodnocení: Zpětná vazba ve výukové komunikaci na druhém stupni základní školy. Studia Paedagogica, 15(2), 61-86.

Šed'ová, K., \& Švařriček, R. (2012). Feedback in educational communication in Czech secondary schools. Educational Assessment, Evaluation and Accountability, 24(3), 239-261.

Švaříček, R., \& Šed'ová, K. (2007). Kvalitativní výzkum v pedagogických vědách. Praha: Portál.

Ten Have, P. (2007). Doing conversation analysis. Thousand Oaks: Sage.

Tulis, M. (2013). Error management behavior in classrooms: Teachers' responses to student mistakes. Teaching and Teacher Education, 33, 56-68.

Tulis, M., Steuer, G., \& Dresel, M. (2016). Learning from errors: A model of individual processes. Frontline Learning Research, 4(2), 12-26.

Tůma, F. (2016). Konverzační analýza a interakce ve třídě: východiska a metodologické aspekty. Pedagogická orientace, 26(3), 415-441.

Tůma, F. (2017). Interakce ve výuce anglického jazyka na vysoké škole pohledem konverzační analýzy. Brno: Masarykova univerzita.

Willemsen, A., N., Gosen, M., van Braak, M., Koole, T., \& de Glopper, K. (2018). Teachers' open invitations in whole-class discussions. Linguistics and Education, 45, 40-49.

Wooffitt, R. (2005). Conversation analysis and discourse analysis: A comparative and critical introduction. Thousand Oaks: Sage.

Yin, R. K. (2011). Qualitative research from start to finish. New York: Guilford Press.

Zander, L., Kreutzmann, M., \& Wolter, I. (2014). Constructive handling of mistakes in the classroom: The conjoint power of collaborative networks and self-efficacy beliefs. Zeitschrift Fur Erziehungswissenschaft, 17(5), 205-223.

Zeman, J. (2013). Verbální a neverbální prostředky v komunikaci mládeže. Hradec Králové: Gaudeamus.

\section{Autor}

Mgr. Martin Majcík, Ústav pedagogických věd, Filozofická fakulta, Masarykova univerzita, Arne Nováka 1, 60200 Brno, e-mail: majcik@phil.muni.cz 


\title{
Practices used by teachers in relation to errors during whole class interaction
}

\begin{abstract}
The goal of the research is to identify practices which are chosen by teacher because of pupils' error. The research is focused on the practices that relate to errors made during whole class interaction. A definition of error and its development is introduced in the theoretical part. Further, the paper deals with teacher error management behaviour. The research is qualitative, and methods of observation and interviews were used. The data was collected in the ninth grade of elementary school in Czech language lessons. The result of our research is the definition of four practices which are part of dealing with errors. The first two procedures represent the way teachers react to error. They are characterized as an adaptive reaction to error and a relativization of the wrong answer. The other two teachers' procedures influence the meaning of error in the social environment of the classroom. They are termed as a prevention from error for selected pupils and a minimization of negative conception of an error.
\end{abstract}

Keywords: error, mistake, teachers' practices, error management behaviour, dealing with errors, pedagogical communication, whole class interaction

Tůma, F. (2017). Interakce ve výuce anglického jazyka na vysoké škole pohledem konverzační analýzy. Brno: Masarykova univerzita.

Monografie je věnována problematice interakce tř́dě. Vychází z 987 minut nahrávek seminární výuky angličtiny. Pomocí konverzační analýzy kniha popisuje, jak se účastníci výuky stř́dali, jak prováděli opravy, jak přepínali mezi angličtinou a češtinou a jak realizovali studentské prezentace. Monografie podrobně zkoumá interakci ve výuce anglického jazyka, ale klade si také za cíl přispět do diskusí o výzkumu interakce (nejen) ve tř́iě. 


\section{Příloha: Transkripční značky (Ten Have, 2007)}

[

]

$=$

(.)

(1)

$\underline{\text { Slovo }}$

::: $\quad$ prodloužení hlásky

- ukončení repliky

. pokles intonace

, malá změna intonace

SLOVO zvýšení hlasu

<slovo> zrychlení

( ) úsek, který nelze přepsat

(slovo) špatně srozumitelné slovo

(C ( ) popis neverbálních aktivit a poznámky 